Volume. 8 Nomor. 2, Mei 2021. p - 2354-8649 I e - 2579-5767

Open Access at: http://ojs.umrah.ac.id/index.php/selat

DOI: https://doi.org/10.31629/selat.v8i2.3830

\title{
PENERAPAN SANKSI HUKUM GAWAL (KAWIN PAKSA) \\ DALAM PENYELESAIAN PELANGGARAN KESUSILAAN DI KECAMATAN TUNGKAL ULU KABUPATEN TANJUNG JABUNG BARAT JAMBI
}

\author{
Erdianto Effendi \\ Fakultas Hukum Universitas Riau \\ erdianto.effendi@gmail.com
}

\begin{abstract}
The application of customary criminal sanctions in the Malay community in Tungkal Ulu District in the past was a gawal penalty (forced marriage). Viewed from the aspect of human rights, forced marriage is often considered as a form of human rights violation. Through this research, it is concluded that forced marriage (gawal) in the Tungkal Ulu Malay community does not constitute a violation of human rights because it is carried out on the basis of justification by the local social system and is not something that is against the wishes of the forced partner. Even gawal is basically wanted by the couple.
\end{abstract}

Keywords; Forced Marriage (Gawal), Human Rights, Customary Law.

\begin{abstract}
Abstrak
Penerapan sanksi pidana adat dalam masyarakat Melayu di Kecamatan Tungkal Ulu pada masa lalu adalah dengan hukuman gawal (kawin paksa). Dilihat dari aspek hak asasi manusia, kawin paksa sering dianggap seagai entuk pelanggaran hak asasi manusia. Melalui penelitian ini disimpulkan bahwa kawin paksa (gawal) pada masyarakat Melayu Tungkal Ulu tidak merupakan pelanggaran hak asasi manusia karena dilakukan dengan dasar pembenaran oleh system sosial setempat dan bukan merupakan sesuatu yang bertentangan dengan keinginan pasangan yang dipaksa. Bahkan gawa pada dasarnya diinginkan oleh pasangan tersebut.
\end{abstract}

Kata kunci; Kawin Paksa (Gawal), Hak Asasi Manusia, Hukum Adat. 


\section{PENDAHULUAN}

Berbeda dengan sistematika hukum pidana nasional yang menempatkan tindak pidana terhadap keamanan negara sebagai tindak pidana pertama yang paling serius hukum adat khususnya dalam hal ini hukum adat masyarakat Melayu di Tungkal Ulu Provinsi Jambi menempatkan tindak pidana yang paling serius adalah tindak pidana kesusilaan. Hukum Adat dalam hal ini Hukum Adat Jambi (termasuk di dalamnya hukum adat Tungkal Ulu) memberi perhatian khusus kepada masalah-masalah perzinahan ini. Terdapat empat macam kesalahan yang dalam adat disebut sebagai kesalahan besar yaitu :

a) menikam bumi, berzinah dengan ibu sendiri

b) mencarak telur, berzinah dengan anak atau orang-orang perempuan yang seharusnya dalam perlindungan.

c) Menyunting bungo setangkai, yaitu berzinah dengan saudara istri

d) Mandi di pancuran gading, berzinah dengan istri pembesar atau istri orang lain. ${ }^{1}$

Rajo Bujang dkk, menyebutkan bahwa hukum adat yang berlaku di Tungkal Ulu adalah Hukum Adat Jambi, seperti tertuang dalam Pucuk Undang-undang nan Delapan dan Undang-undang nan Dua Belas. Pada dasarnya, pengaturan masalah yang diatur dalam Induk Undang Nan Delapan dan Anak Undang Nan Duabelas meliputi :

Pucuk Undang nan Delapan :

a) Pengaturan masalah pemberontakan (dago dagi)

b) Pengaturan masalah kesusilaan (sumbang salah)

c) Pengaturan masalah perampokan (samun sakai)

d) Pengaturan masalah pembunuhan dengan racun (Upas racun)

e) Pengaturan masalah pembakaran rumah atau kampun (Siur Bakar)

f) Pengaturan masalah penipuan (tipu tepo)

g) Pengaturan masalah pencurian (Maling curi)

h) Pengaturan masalah pembunuhan dengan senjata (tikam bunuh)

${ }^{1}$ Anonim, Buku Pedoman Adat Jambi, Lembaga Adat Propinsi Jambi dan Pemda Tingkat I Jambi, Jambi, 1993, hal. 30 . 
Sedangkan Anak Undang nan Duabelas meliputi pengaturan masalah hubungan dengan Allah, hubungan sesama manusia, masalah hubungan antar rumah tangga (rumah nan betengganai, luhak nan bepenghulu, negeri yang bebatin, rantau nan bejenang, alam nan berajo), masalah yang berkaitan dengan sanksi atas luka, mati, hutang piutang, pinjam meninjam, dan merusakkan, masalah yang berkaitan dengan perkawinan, masalah yang berkaitan dengan penghidupan atau mata pencaharian, masalah yang berkaitan dengan permainan, dan masalah yang berkaitan dengan hak negara atas hasil usaha penduduk.

Dengan demikian, isi atau materi dari Pucuk undang-undang nan Delapan mencakupi tindakan yang dalam hukum positif disebut hukum pidana dan Anak Undang-undang nan Duabelas mencakupi hubungan yang dalam hukum positif disebut hukum perdata. Dengan demikian, sesungguhnya tidak ada perbedaan antara hukum pidana dengan hukum perdata dalam sistematika hukum adat sehingga tidak ada pula istilah tindak pidana. Namun karena penulisan makalah dilakukan dengan pendekatan hukum modern, maka istilah yang digunakan adalah tindak pidana adat.

Pada masyarakat Melayu di Tungkal Ulu, terdapat ketentuan khusus pula tentang tata pergaulan antara bujang dan gadis maupun antara laki-laki dan perempuan yang sudah kawin antara lain :

a) Tebus talak, yaitu sanksi hukum yang dijatuhkan kepada seorang laki-laki yang berbuat serong denga istri orang lain baik sama-sama setuju maupun perkosaan. Jika suka sama suka sanksinya dibebankan kepada kedua belah pihak, dan laki-laki dan perempuan itu dikawinkan. Jika diperkosa sanksi dibebankan kepada si laki-laki saja. Adapun sanksinya adalah memberi ganti rugi kepada suami si perempuan.

b) Gawal, yaitu sanksi berupa kawin secara adat oleh pemuka adat dan membayar biaya cuci kampung apabila ditemukan oleh oleh waris perempuan (saudara laki-lakinya, atau pamannya) keadaan dimana seorang bujang dan gadis melakukan pergaulan bebas. 
c) Tehiruk tegempar, sama saja denga gawal, tetapi yang menemukan bukan dari keluarga perempuan melainkan orang lain yang tidak ada hubungan dengan si laki-laki dan perempuan. ${ }^{2}$

Dari tiga bentuk sanksi adat di atas, yang paling serius adalah sanksi "gawal".

\section{METODE PENELITIAN}

Penelitian hukum empiris setidaknya terdiri dari dua bentuk yaitu (1) penelitian terhadap identifikasi hukum (hukum tidak tertulis) dan (2) penelitian terhadap efektifitas hukum. ${ }^{3}$ Dalam penelitian tentang penggunaan lembaga gawal dalam penyelesaian perkara tindak pidana kesusilaan, digunakan metode penelitian hukum empiris khususnya penelitian terhadap hukum yang hidup di Provinsi Jambi. Yang menjadi objek penelitian ini adalah Kecamatan Tungkal Ulu Kabupaten Tanjung Jabung Barat Provinsi Jambi yang terdiri dari 9 desa/kelurahan yaitu Pelaabuhan Dagang, Gemuruh, Kuala Dasal, Brasau, Taman Raja, Pematang Tembesu, Tanjung Tayas, Pematang Pauh, Badang dan Badang Sepakat.

Untuk mendapatkan gambaran yang lebih representative tentang penggunaan lembaga gawal dalam penyelesaian perkara tindak pidana kesusilaan di Kecamatan Tungkal Ulu, maka akan dipilih sample desa sebanyak 10 \% dari jumlah keseluruhan kecamatan yang ada di Kecamatan Tungkal Ulu. Pemilihan sample kabupaten/kota dilakukan dengan metode area atau cluster sampling yaitu metode penentuan sample dengan menentukan terlebih dahulu beberapa area dari keseluruhan populasi. Adapun kriteria yang digunakan untuk menentukan sample dalam penelitian ini adalah keterwakilan wilayah utara dan selatan, serta pesisir dan perbukitan. Dengan metode ini diharapkan tergambar secara keseluruhan berdasarkan karakteristik wilayah geografis dan penduduk secara lebih variatif.

Untuk mengumpulkan data, peneliti melakukan studi kepustakaan (library research) dan study lapangan (field research). Studi kepustakaan dilakukan di beberapa pustaka guna mengumpulkan data sekunder dalam bentuk hukum primer seperti undang-undang, bahan hukum sekunder seperti buku-buku hukum dan bahan hukum tertier seperti jurnal hukum dan majalah, yang kesemuanya berfungsi

\footnotetext{
2 Rajo Bujang dkk, Dinamika Adat Masyarakat Kabupaten Tanjung Jabung Barat, Lembaga Adat Kabupaten Tanjung Jabung Barat, Kuala Tungkal, 2003, hal.85-86.

${ }^{3}$ Soerjono Soekanto, Pengantar Penelitian Hukum, Jakarta : UI Press, Jakarta, 1986, hlm.51.
} 
sebagai informasi lini pertama (first line information). Dalam studi lapangan, peneliti menyebarkan kuesioner kepada para tokoh adat dan ulama setempat serta tokoh adat Kecamatan Kemuning. Penentuan sample penegak hukum dilakukan dengan metode purposive sampling. Untuk melengkapi data hasil penelitian, peneliti juga akan melakukan wawancara terstruktur kepada para pelaku tindak pidana kesusilaan yang ada di 9 desa yang menjadi objek penelitian.

Alat pengumpul data yang digunakan dalam penelitian ini adalah kuesioner dan wawancara yang telah disiapkan terlebih dahulu, ditujukan kepada sample penegak hukum, pelaku dan korban. Untuk menyimpulkan hasil penelitian guna mencapai hasil yang obyektif, data disusun, diklasifikasikan, dicatat dan dianalisa secara kualitatif. Penyusunan data bertujuan untuk menyeleksi data yang relevan dengan penelitian ini.

\section{PEMBAHASAN}

\subsection{Implementasi Hukum Gawal Di Desa-Desa Di Kecamatan Tungkal Ulu Penyelesaian Perkara Tindak Pidana Kesusilaan Saat Ini}

Tungkal Ulu yang menjadi objek penelitian ini adalah salah satu kecamatan dalam wilayah Kabupaten Tanjung Jabung Barat Provinsi Jambi. Salah satu hal yang dewasa ini banyak menjadi sorotan ahli hukum pidana adalah tentang penerapan asas legalitas sebagaimana diatur dalam Pasal 1 KUHP. Pasal 1 KUHP menentukan bahwa tiada suatu perbuatan boleh dihukum, melainkan atas kekuatan ketentuan pidana dalam Undang-undang, yang ada terdahulu dari pada perbuatan itu. ${ }^{4}$ Oleh karena itu, bagi penegak hukum Indonesia saat ini, satu-satunya sumber penyelesaian sengketa dalam hukum pidana adalah undang-undang dalam hal ini KUHP dan hukum pidana khusus.

Penerapan asas legalitas di Indonesia menimbulkan masalah besar bagi penegakan hukum pidana yang berkisar pada setidaknya dua hal yaitu banyaknya tumpukan perkara yang tidak dapat diselesaikan oleh sub sistem peradilan pidana dan adanya over kapasitas di lembaga-lembaga pemasyarakataan di seluruh Indonesia. Masalah over kapasitas menjadi fenomena umum di seluruh lapas di

\footnotetext{
${ }^{4}$ R. Soesilo, KUHP, Politeia,Bogor, 1996
} 
Indonesia dan telah menjadi hasil penelitian dan kajian banyak ahli dan peneliti hukum seperti salah satunya adalah penelitian Angkasa. ${ }^{5}$

Untuk mengatasi persoalan-persoalan tersebut, dewasa ini timbul gagasan untuk memberlakukan kembali penyelesaian perkara pidana dengan cara yang lazim berlaku di tengah kelompok masyarakat yang bersangkutan. Itulah yang sering disebut sebagai local-wisdom. Para ahli juga sering menamakan local-knowledge. 6 Dalam buku berjudul The turning point of civilization, Fritjof Capra justru mengungggulkan pikiran Timur dibanding Barat dan karenanya mengusulkan perlunya kembali menggali nilai-nilai peradaban Timur. ${ }^{7}$

Di seluruh daerah di Indonesia dikenal berbagai bentuk tradisi budaya setempat sebagai kearifan lokal masyarakat setempat dalam menyelesaikan masalah yang dihadapi tanpa melibatkan pihak-pihak berwenang yang lebih mengedepankan harmoni di tengah masyarakat daripada aspek retributive (pembalasan dendam) tidak terkecuali dalam penyelesaian pelanggaran kesusilaan seperti perzinahan, perkosaan dan pencabulan. Meskipun dinilai sejalan dengan nilai-nilai yang hidup di tengah masyarakat Indonesia, sebagian besar peraturan perundang-undangan masih menggunakan pendekatan retributif dalam penyelesaian perkara pidana. Konsep restoratif dalam penyelesaian perkara pidana di Indonesia sejauh ini baru dikenal dalam penyelesaian perkara pidana anak.

Prosesi hukum gawwal adalah dengan cara menangkap basah sepasang muda mudi atau siapa saja laki-laki dan perempuan yang bukan muhrim walaupun keduanya telah menikah, atau salah satunya saja yang telah menikah yang kedapatan sedang berduaan di suatu tempat. Yang memergoki adalah warga setempat dengan didampingi salah seorang pihak keluarga laki-laki dari pihak perempuan. Setelah dipergoki mereka dibawa ke rumah ketua adat atau Penghulu (Kepala Desa di masa lalu) lalu Penghulu memanggil kedua orang tua dari kedua belah pihak. Para pihak ditanyakan alasan mereka berdua, juga ditanyakan pendapat tetua adat yang telah

\footnotetext{
5 Angkasa, "Over Capacity Narapidana Di Lembaga Pemasyarakatan, Faktor Penyebab, Implikasi Negatif, Serta Solusi Dalam Upaya Optimalisasi Pembinaan Narapidana." Jurnal Dinamika Hukum, Vol 10 No.3 tahun 2010, Fakultas Hukum Universitas Jenderal Soedirman, Purwokerto.

6 Marcus J. Pattinama, "Pengentasan Kemiskinan dengan Kearifan Lokal”, Jurnal Makara, Sosial Humaniora, Vol. 13, No. 1, Juli 2009: 1-12, hl.3-4.

7 Fritjof Capra sebagaimana dikutip Satjipto Rahardjo, "Hukum Progresif, Kesinambungan, Merobohkan dan Membangun", Jurnal Hukum Progresif Vol 2 Nomor 1 April 2006, Program Doktor Ilmu Hukum Universitas Diponegoro, Semarang, hlm.6.
} 
berkumpul dan sampailah ketua adat atau penghulu pada keputusan yaitu menghukum kedua elah pihak dengan seekor kambing yang dagingnya dimakan bersama selurug warga kampung. Hukuman tambahan selain denda seekor kambing adalah diwajikannya mereka berdua menikah. Proses pengambilan keputusan dilakukan dengan model yurisprudensi karena membandingkan dengan kasus yang terjadi di masa lalu aru diambil suatu keputusan.

Menurut Elviarita, SE, Lurah Pelabuhan Dagang, secara normatif hukum gawal masih diakui ada dalam masyarakat Melayu di Tungkal Ulu, namun penerapannya sudah tidak bisa dilakukan sebagaimana masa lalu. Penerapan gawal masih terjadi dan tidak pernah diterapkan lagi di willayahnya sejak tahun 1985. Pada tahun 1985 seorang Pegawai Negeri Sipil dengan nama inisial LS didapati oleh warga sedang berduaan di mess Pegawai Negeri Sipil Kecamatan Tungkal Ulu dengan seorang gadis setempat dengan inisial nama HF. Mereka dipaksa menikah dan hingga kini telah dikarunia 3 orang anak. Anak pertama mereka saat ini telah kuliah di Akademi Kebidanan di Kota Jambi.

Menurut pengakuan LS hukum gawal yang diterapkan kepada mereka bukan merupakam sesuatu yang berarti nestapa atau penderitaan sebagai arti pidana itu sendiri. Bagi LS saat itu ia tidak merasakan itu sebagai hukuman, karena pada kenyataannya ia memang mencintai HF dan HF pun mencintai dirinya.

Tidak demikian dengan perasaan kedua orang tua HF (orang tua LS bukan penduduk setempat). Jika anak dikenakan hukum gawal itu berarti malu besar tercoreng di wajah kedua orang tua dan keluarga besarnya. Bagi orang Melayu, lebih baik mati anak daripada mati adat. Hidup tanpa mematuhi adat seumpama berjalan tanpa busana, tanpa kedudukan dan tanpa harga diri. Dengan diterapkannya hukum gawal itu berari anak gadis keluarga Melayu tidakk menerima "hantaran belanjo" sejenis maskawin menurut adat. Makin tinggi status si gadis dan orang tua, maka makin besar uang "hantaran belanjo", semakin rendah status sosial seorang gadis dan keluarganya, makin kecil pula uang "hantaran belanjo". Gadis yang dipaksa menikah karena gawal tidak boleh menerima "hantaran belanjo" bahakan tidak ada resepsi pernikahan agi kedua mempelai. Mereka hanya menikah "tegak syarak" yaitu menikah secara agama Islam saja tanpa walimah atau resepsi. 
Di Desa Taman Raja, seperti di Pelabuhan Dagang, hukum gawal juga juga tidak lagi diterapkan. Akan tetapi pada masa lalu seperti disampaikan Farizal yang saat ini menjabat seagai Ketua Koperasi Taman Raja, 10 tahun yang lalu hukum gawal pernah diterapkan pada pasangan muda mudi R dengan L. Pasangan tersebut hingga kini sudah beranak pinak bahkan sudah punya cucu.

Dewasa ini, walaupun hukum gawal tidak lagi djumpai namun sanksi hukum adat membayar denda kambing masih terjadi dalam kasus yang serupa. Pada masyarakat Adat Pelabuhan Dagang seorang yang menikah secara agama tetapi tidak mellaporkan kepada Keetua Adat juga akan mendapat sanksi berupa membayar seekor kambing.

Hal itu disebabkan oleh karena pada masa kini pergaulan laki-laki dan perempuan tidak bisa dibatasi lagi seperti dahulu. Sulit ditemukan laki-laki dan perempuan "duduk bebandung duo". Namun jika memang ditemukan tertangkap tangan dalam kelambu, maka hukum gawal tetap diterapkan. ${ }^{8}$

Dalam hal ini telah terjadi pergeseran nilai dalam masyarakat. Perilaku muda mudi yang dulu tau untuk berdua-duaan, di masa sekarang dianggap perilaku biasa. Akiatnya adalah banyak anak gadis yang hamil di luar nikah. Setelah hamil baru dinikahkan.

Dalam perkembangan masyarakat kita dewasa ini, khususnya setelah dihapuskannya pemerintahan Marga, hukum adat yang berkaitan dengan Pucuk Undang nan Delapan dan Anak Undang nan Duabelas seolah seperti ditinggalkan karena telah efektifnya pemberlakuan Hukum Pidana dan Hukum Perdata Positif ditambah lagi diakuinya keberlakuan Hukum Islam terhadap beberapa aspek kehidupan masyarakat. Hal ini sejalan dengan pepatah adat yang berbunyi " hak rajo balik ke rajo, hak batin balik ke batin, hak penghulu balik ke penghulu, dst." Itu berarti bahwa dengan bergantinya Kerajaan menjadi Negara Republik maka segala hukum yang disebut hak rajo berubah menjadi wewenang negara.

Salah satu kejadian baru-baru ini di Kelurahan Pelabuhan Dagang adalah diketahuinya sepasang muda mudi yang hami di luar nikah tidak dapat dinikahkan

\footnotetext{
8 Wawancara dengan Bapak Syamsurizal, Ketua Lembaga Adat Kelurahan Pelauhan Dagang, tanggal 26 April
} 2017. 
karena umur mereeka di awah usia yang seharusnya boleh menikah sehingga harus mendapat rekomendasi dari Pengadilan Agama baru dapat dinikahkan.

\subsection{Praktik Hukum Gawal dilihat dari Aspek Hak Asasi Manusia, Hukum Perdata dan Hukum Pidana}

Hukuman menikah paksa jika diliihat dari aspek hak asasi manusia adalah entuk pelanggaran Hak Asasi Manusia. Dalam Pasal 16 dinyatakan ahwa (1) Laki-laki dan Perempuan yang sudah dewasa, dengan tidak dibatasi kebangsaan, kewarganegaraan atau agama, berhak untuk menikah dan untuk membentuk keluarga. Mereka mempunyai hak yang sama dalam soal perkawinan, di dalam masa perkawinan dan di saat perceraian. (2) Perkawinan hanya dapat dilaksanakan berdasarkan pilihan bebas dan persetujuan penuh oleh kedua mempelai.

Dalam pandangan Islam pun demikian adanya, Seorang perempuan dewasa, Dalam pandangan mayoritas para ulamâ, dianggap telah memiliki kemampuan untuk melakukan tindakan-tindakan hukum yang berhubungan dengan transaksi-transaksi keuangan, seperti perdagangan, kepegawaian, dan sebagainya. Oleh karena itu, sangat logis jika perempuan juga dapat melakukan tindakan-tindakan yang berkaitan dengan urusan pribadinya, 4 termasuk menentukan pasangan hidupnya. ${ }^{9}$

Pelanggaran HAM dalam bentuk pemaksaan kehendak, berpikir, dan penyiksaan fisik terhadap perempuan ternyata masih banyak terjadi. Sebut saja bride kidnaping atau penculikan terhadap (calon pengantin) perempuan, masih terjadi di Kyrgyztan dan Turkmenistan, dua buah wilayah pecahan bekas negara Soviet. Dalam praktiknya, lelaki beserta keluarganya menculik perempuan yang hendak dinikahi. Perempuan tersebut dibawa secara paksa ke rumah keluarga lelaki, hingga berharihari sampai perempuan menyerahkan diri dan bersedia untuk dinikahi lelaki tersebut. Di Indonesia peristiwa ini dikenal dengan istilah "merarik" yang terjadi di Lombok, Nusa Tenggara Barat. ${ }^{10}$

Untuk kasus nikah paksa tersebut, di Indonesia yang terjadi beda lagi. Anakanak perempuan Pulau Buru, di hadapan tradisi mereka harus pasrah dipinang

\footnotetext{
9 Abu Bakar, Kawin Paksa, Problem Kewenangan Wali dan Hak Perempuan dalam Penentuan Jodo Dalam http://ejournal.stainpamekasan.ac.id/

10 Hafidzohalmawaliy, Perempuan dan HAM : Agama, Perempuan dan Hak Asasi Manusia https://hafidzohalmawaliy.wordpress.com/2008/07/08/
} 
dalam usia belia. Terkadang, kala mereka masih berusia enam tahun, atau bahkan saat masih dalam kandungan. Mereka dipinang oleh lelaki dewasa yang sedang mencari istri. Ketika pinangan sudah dilakukan, sang anak dilarang bersekolah dan kadang juga dilarang untuk bergumul dengan kawan sebaya, seakan tidak boleh mengenal dunia luar. Mereka menyebutnya sebagai "kawin piara". Anak-anak perempuan itu akan dipelihara sampai dianggap telah siap untuk menjadi ibu dan mengurus rumah tangga. Mereka dipertukarkan oleh ayahnya karena memang di sana perempuan bisa dipertukarkan sebagaimana barang. Bahkan terkadang mereka juga diteruskan pada laki-laki lain dalam satu keluarga jika suaminya meninggal agar persaudaraan di antara kedua keluarga tidak terputus.

Berbeda dengan praktik kawin paksa di dua daerah lain sebagaimana yang dilaporkan Hafidzohalmawaliy, kawin paksa melalui hukum gawal berbeda dengan yang terjadi di Tungkal Ulu. Yang hampir serupa dengan kawin paksa di Tungkal Ulu adalah di beberapa daerah lain seperti di Bengkulu, Sumatra Barat, Aceh dan Nusa Tenggara Barat. Menurut catatan Istitut Perempuan, tradisi kawin paksa di Indonesia sendiri dikenal di beberapa daerah. Misalnya kawin grebeg di Bengkulu, dimana kawin grebeg ini sering digunakan oleh laki-laki yang menyukai perempuan tetapi perempuan menolaknya. Selain itu ada pula tradisi mudemu di Aceh, kawin tangkap di Sumatera Barat, kawin maghrib di suku Sasak. Tradisi semacam ini merupakan salah satu tradisi yang mempromosikan nilai-nilai kekerasan terhadap perempuan.

Namun demikian, kawin paksa (Gawal) tetap lah berbeda. di Tungkal Ulu yang terjadi diseabkan adanya pelanggaran oleh kedua belah pihak. Atas perbuatan yang menuurut nilai hukum adat setempat sebagai perbuatan yang amat tercela. Karena didukung oleh sistem sosial yang berlaku pada masyarakat setempat, maka penerapan kawin paksa dengan model hukum gawal bukanlah bentuk pelanggaran Hak Asasi Manusia.

Ada kalanya praktik gawal memang diinginkan oleh kedua pihak laki-laki dan perempuan karena dengan diterapkannya hukum gawal bagi mereka, mereka terbebas dari kewajiban adat berupa membawa "hantaran belanjo" yang jumlahnya agi seagian laki-laki amat berat yang menjadi penghalang dilaksanakannya pernikahan. 
Praktik serupa bahkan masih terjadi di perkotaan. Di Kota Pekanbaru, berdasarkan penelitian Erdianto diketahui bahwa di beberapa tempat khususnya di lokasi sekitar kampus Universitas Islam Riau di kawasan Marpoyan Damai dan kawasan sekitar kampus Universitas Riau di Simpang Baru, Tampan. 11 Terhadap pelaku kesusilaan yang tertangkap tangan oleh masyarakat dikenakan sanksi berupa membayar denda untuk membangun fasilitas milik warga seperti posyandu, fasilitas olahraga dan lain sebagainya. Besarnya bisa hingga mencapai 5 juta rupiah. Pemberian sanksi tersebut dilakukan atas dasar kesepakatan warga dan pimpinan RT atau RW setempat dan pelaku. ${ }^{12}$ Namun demikian, penerapan sanksi pidana adat bagi warga hanya dapat dilakukan atas kasus pelanggaran kesusilaan. Terhadap kasus-kasus tindak pidana lainnnya, masyarakat lebih suka menyerahkan pelaku kepada pihak berwajib. Perbedaannya dengan yang terjadi di Kecamatan Tungkal Ulu adalah dimana pada masyarakat Kota Pekanbaru, tidak ada pengenaan hukuman kawin paksa.

Pada awal September 2015, publik digegerkan dengan rencana kebijakan yang akan dikeluarkan Pemkab Purwakarta yaitu penggerebekan dan kawin paksa bagi sepasang remaja yang berpacaran melewati jam 21.00. Menurut Bupati Purwakarta Dedi Mulyadi, kebijakan ini bakal diterapkan di semua desa dan kelurahan di Purwakarta secara serempak pada September 2015. Menurut Dedi Mulyadi, latar belakang dari kebijakan ini adalah agar tidak terjadi kasus-kasus asusila yang merusak akhlak remaja serta sebagai respons dari banyaknya kasus remaja hamil di luar nikah. Semua kepala desa dan lurah diwajibkan membuat peraturan desa untuk mengatur hal ini selambatnya pada September 2015.

Institut Perempuan (http://www.institutperempuan.or.id/) memandang bahwa kebijakan kawin paksa ini mengartikan bahwa Pemda Kabupaten Purwakarta mendukung terjadinya kekerasan seksual terhadap anak perempuan/remaja perempuan. Perlu diketahui, kawin paksa merupakan salah satu bentuk kekerasan seksual. Komisi Nasional Anti Kekerasan terhadap Perempuan telah mengidentifikasi 15 bentuk kekerasan seksual, dimana salah satu bentuk kekerasan seksual di Indonesia adalah pemaksaan perkawinan yaitu situasi dimana perempuan dipaksa

11 Erdianto, Eksistensi Tepung Tawar pada Masyarakat Melayu Riau, Jurnal Dinamika Hukum, Universitas Jendeeral Soedirman, Volume 1 Tahun 2015..

12 Ibid 
melakukan perkawinan di luar kehendaknya sendiri. Oleh karena itu, rencana kebijakan yang dikeluarkan oleh Bupati Purwakarta ini merupakan kategori kekerasan seksual.

Dilihat dari perspektif hukum perdata, perkawinan paksa seperti yang dulu diterapkan di Tungkal Ulu tidak bertentangan dengan Undang-undang Perkawinan. Undang-undang Perkawinan menyatakan bahwa perkawinan sah apabila dilakukan menurut agama dan kepercayaan masing-masing.

Praktik di Tungkal Ulu, perkawinan dengan model gawal tidak otomatis selesai karena gawal hanyalah proses permulaan. Proses selanjutnya adalah denga menikahkan pihak yang melanggar norma adat dengan hukum syariah yaitu hukum Islam dan selanjutnya dicatatkan di Kantor Urusan Agama Kecamatan. Dengan demikian, sah lah secara hukum perkawinan yang dimulai dari hukum gawal tersebut. Proses yang terlampaui hanyalah proses adat.

Dilihat dari aspek hukum pidana, pengenaan sanksi berupa penjatuhan hukuman kawin paksa memang tidak dikenal dalam sistem pemidanaan dalam hukum pidana. Bentuk sanksi pidana dalam hukum pidana Indonesia adalah terdiri dari pidana pokok dan pidana tambahan. Pidana pokok yaitu pidana mati, pidana penjara, pidana kurungan dan pidana denda. Sedangkan pidana tambahan meliputi pencabutan hak tertentu, perampasan barang tertentu dan pengumuman putusan hakim. Meskipun tidak dikenal dalam sistem hukum pidana positif di Indonesia, dalam beerapa putusan peradilan Indonesia, penerapan sanksi adat khususnya di Bali diakui oleh sistem hukum pidana Indonesia.

\section{KESIMPULAN}

Berdasarkan pembahasan di atas, maka dapat disimpulkan bahwa model penyelesaian perkara kesusilaan dengan hukum gawal pada masyarakat Melayu Tungkal Ulu masih diakui secara normatif walaupu saat ini tidak lagi diterapkan. Penerapan hukum gawal tidak pertentangan dengan Hak Aasi Manusia karena merupakan sistem nilai yang berlaku sebagai kearifan lokal dan tidak dilakukan tanpa persetujuan kedua belah pihak. 


\section{DAFTAR PUSTAKA}

Abu Bakar, Kawin Paksa, Problem Kewenangan Wali dan Hak Perempuan dalam Penentuan Jodo Dalam http://ejournal.stainpamekasan.ac.id/

Angkasa, “Over Capacity Narapidana Di Lembaga Pemasyarakatan, Faktor Penyebab, Implikasi Negatif, Serta Solusi Dalam Upaya Optimalisasi Pembinaan Narapidana." Jurnal Dinamika Hukum, Vol 10 No.3 tahun 2010, Fakultas Hukum Universitas Jenderal Soedirman, Purwokerto.

Anonim, Buku Pedoman Adat Jambi, Lembaga Adat Propinsi Jambi dan Pemda Tingkat I Jambi, Jambi, 1993.

Erdianto, Eksistensi Tepung Tawar pada Masyarakat Melayu Riau, Jurnal Dinamika Hukum, Universitas Jendeeral Soedirman, Volume 1 Tahun 2015.

Fritjof Capra sebagaimana dikutip Satjipto Rahardjo, "Hukum Progresif, Kesinambungan, Merobohkan dan Membangun”, Jurnal Hukum Progresif Vol 2 Nomor 1 April 2006, Program Doktor Ilmu Hukum Universitas Diponegoro, Semarang.

Hafidzohalmawaliy, Perempuan dan HAM : Agama, Perempuan dan Hak Asasi Manusia https://hafidzohalmawaliy.wordpress.com/2008/07/08/

Marcus J. Pattinama, "Pengentasan Kemiskinan dengan Kearifan Lokal", Jurnal Makara, Sosial Humaniora, Vol. 13, No. 1, Juli 2009: 1-12.

R. Soesilo, KUHP, Politeia,Bogor, 1996.

Rajo Bujang dkk, Dinamika Adat Masyarakat Kabupaten Tanjung Jabung Barat, Lembaga Adat Kabupaten Tanjung Jabung Barat, Kuala Tungkal, 2003.

Soerjono Soekanto, Pengantar Penelitian Hukum, Jakarta : UI Press, Jakarta, 1986. 